\title{
AN ANALYSIS OF IMPACT OF EVIDENCE BASED LEARNING ON ACADEMIC ACHIEVEMENT OF STUDENTS
}

\author{
Prashant Thote ${ }^{*}{ }^{凶}$, Gowri. S 2 \\ ${ }^{* 1}$ Gyanodaya Vidya Mandir, India
}

DOI: https://doi.org/10.29121/granthaalayah.v8.i8.2020.869

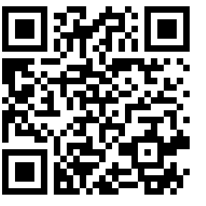

\section{Article Type: Research Article}

Article Citation: Prashant Thote, and Gowri. S (2020). AN ANALYSIS OF IMPACT OF EVIDENCE BASED

LEARNING ON ACADEMIC ACHIEVEMENT OF STUDENTS. International Journal of Research GRANTHAALAYAH, 8(8), 207-216. https://doi.org/10.29121/granthaa layah.v8.i8.2020./869

Received Date: 26 July 2020

Accepted Date: 29 August 2020

Keywords:

Active Learning

Chemistry

Solid States

Crystal Lattice

Unit Cell

\section{ABSTRACT}

The outcome-based learning is leading and has set a new trend in innovative class-room instructions. In Chemistry, the solid-state structures and composite materials are covered in classroom due to its use in day to day life. In this paper attempt is made to present novel handmade model as a tool that provides a desired link between the unit cell representation and extended structure. This model offers visualization stacking pattern that provides simple- unit cell, body- centered and face -centered cubic and hexagonal closed packed cell. Preparing and using molecular handmade model in Teaching-Learning is significant and has a positive impact on academic achievement. The students handmade models acts as a tool for teaching and it has considerable importance in Science education. Totally 40 students of Grade 12 are selected as the sample for the present study. Students are divided into two sets - experimental group and control group. Each group consists of 20 students. Students of the experimental group are asked to make handmade model of unit cells. This handmade model of cells and pieces combines into three corresponding crystal shapes and through this students are taught about the primitive cell of solid state. The control group is taught by using traditional chalk and talk method. The present study is experimental in nature. The pre-test and post-test equivalent group design is used for collecting data. The mean deviation and difference of mean are computed for both groups. The significant differences of both the experimental and the control group based on the variables of pre-test and post-test are tested at 0.05 level by applying t-test. On the completion of statistical analysis of data and research it is concluded that the handmade model of the primitive cells of solid state unit of Chemistry has significant positive effect on the academic achievement of the students in Chemistry at Senior Secondary School level. Based on the findings it is recommended that teachers should use outcome based Teaching-Learning approach to move up student's achievement in core subjects.

\section{INTRODUCTION}

The unit-cells of crystal lattices are traditionally introduced in solid state unit of Chemistry in Grade 12 . The unit cell is the smallest unit and the most representative unit of crystalline material. The unit cell by translation along with three principles of orthogonal planes generates complete crystal lattices. As a Chemistry teacher for 25

(C) 2020 The Author(s). This is an open access article distributed under the terms of the Creative Commons Attribution License, which permits unrestricted use, distribution, and reproduction in any medium, provided the original author and source are credited. 
years, I find that two dimensional (2D) illustrations of unit cell in the unit solid state in Chemistry is not adequate in providing insight about unit cell and crystal lattices and clearly exhibit the physical properties of lattices. Most of the students globally find that the unit solid state in Chemistry is highly abstract in nature and hence not easy to understand. The most common reason is the use of two dimensional representation make the classroom instruction difficult for learners to visualize the three dimensional figures on chalk board and paper. Adequate, efficient and effective three dimensional representations of unit cell and crystal lattices in classroom instructions enhances students visualization of three dimensional figure on chalk board and paper. Concrete hand held model is very effective teaching aid especially for unit cell and crystal lattices to enhance the conceptual understanding. We experience that, though the readymade model of unit cell is available and are used in the classroom instructions; still students are facing challenges to generate sound three dimensional unit cell and crystal lattices because unit cell pieces are opaque and not sufficient in number to form the crystal lattices.

To address these problems of the learner's we device handmade models. Very less information is available relating to the model used by teachers and students in teaching-learning at Senior Secondary School level. My own impression is that many Chemistry teachers for variety of reasons are not using models and hand -made models in their class room instructions for joyful experiences.

Models are an object, usually maintained and are often built according to the scale representative based on something made or something that already exists. The word model is commonly used in day to day language. The model is meaningful to the extent that it should suggest or represent the object of model. Models are significant in communicating and understanding Chemistry. Models provide representation of scientific concept that makes idea more understandable to the student. It requires users to align between the model and the reality that are being modeled.

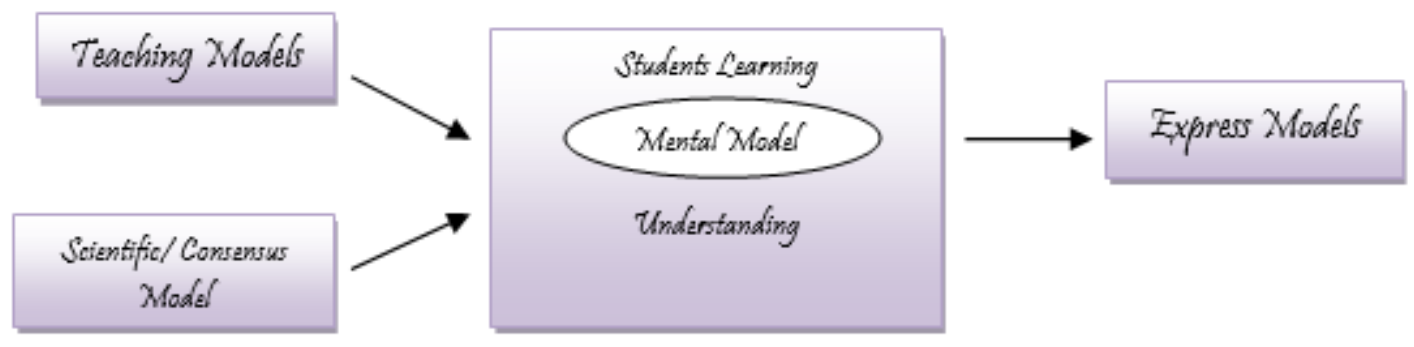

Figure 1: Theoretical Framework of Model in Teaching-Learning Process

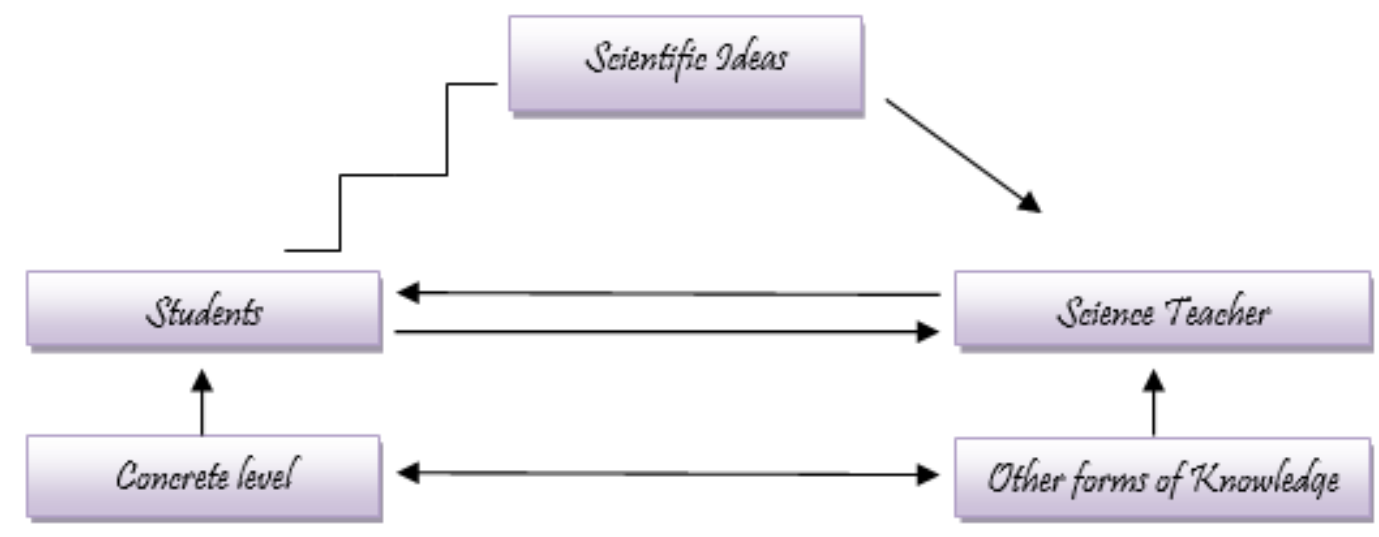

Figure 2: Transformation of subject knowledge into pedagogical content knowledge in Chemistry education

Traditional and stereotype views of scientific enquiry concentrate on individual scientist as enquirers. Knowledge construction is not an individual activity. Scientific communities enable the germination of Science knowledge. In practice, Science is considered to involve the process of producing, making, educating, revision and improvisation of tools that facilitate the growth and development of knowledge. Modeling is a significant instrument for the growth of knowledge. Chemistry generates, evaluates, revises and improves the model explaining the 
representation between the source and a target. It plays a significant role in reasoning, problem solving and justifying the outcomes of learning.

Chemistry is often not considered as an easy, interesting, joyful, experiential learning subject because it relates the phenomena that are not observable to the learners, for example the students cannot see the atomic structure in classroom situation. In Chemistry acute concepts are not easy to understand and to establish relationship between two dimensional representation and corresponding three dimensional things, for example features of structures of solids in Chemistry requires students' capabilities and competence to take two dimensional delegations from chalk board and paper and transform into three dimensional crystal lattices in mind. The crystalline solids have well distinct shapes because of particles/atoms/ions/molecules that occupies in a well-defined orderly arrangement. The particles/atoms/ions/molecules in the crystal lattices are packed in orderly three dimensional arrays. There are fourteen types of unit cell and seven -types of crystal systems in nature exist. Unit cell is a repeating unit of crystal lattice and results from ways of atoms packed together. The cubic system is the first and the simplest in the solid state. The cubic system basically consists of two classes of unit cells. These are primitive and nonprimitive/centered unit cells.

- Primitive unit cells: A unit cell is called primitive unit cell if it has particles (or points) only at the corners. It is also called single unit cell.

- Non-primitive unit cells: In this type of unit cells, particles (or points) are present not only at the corners but also at some other positions. Centered unit cells are also called non-primitive unit cells and these are of three types:

1) Face centered: Particles (or points) are located at the corners and also in the centre of each face.

2) Body centered: Particles (or points) are located at the corners and also at the center of each face.

3) End face centered: Particles (or points) are located at the corners and also at the center and also at the centers of any two opposite faces.
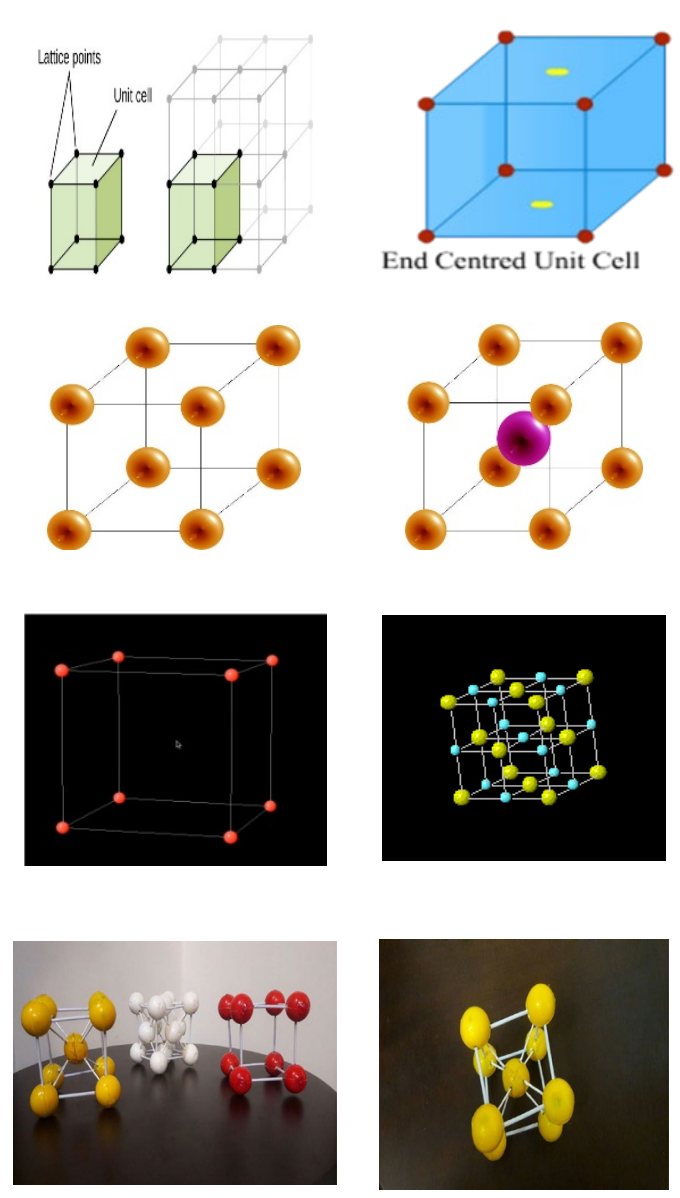

\section{Hand Made Model}
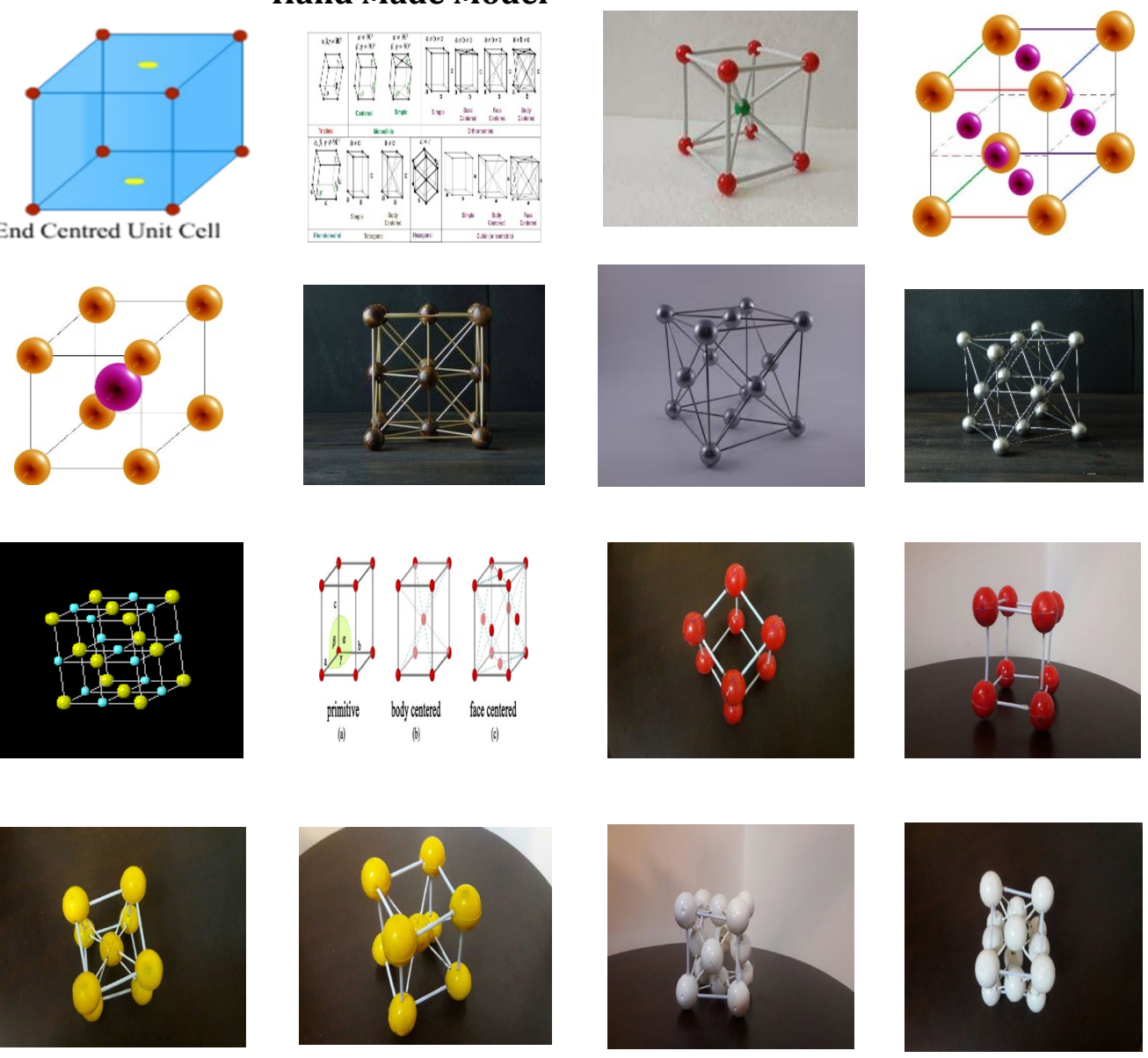

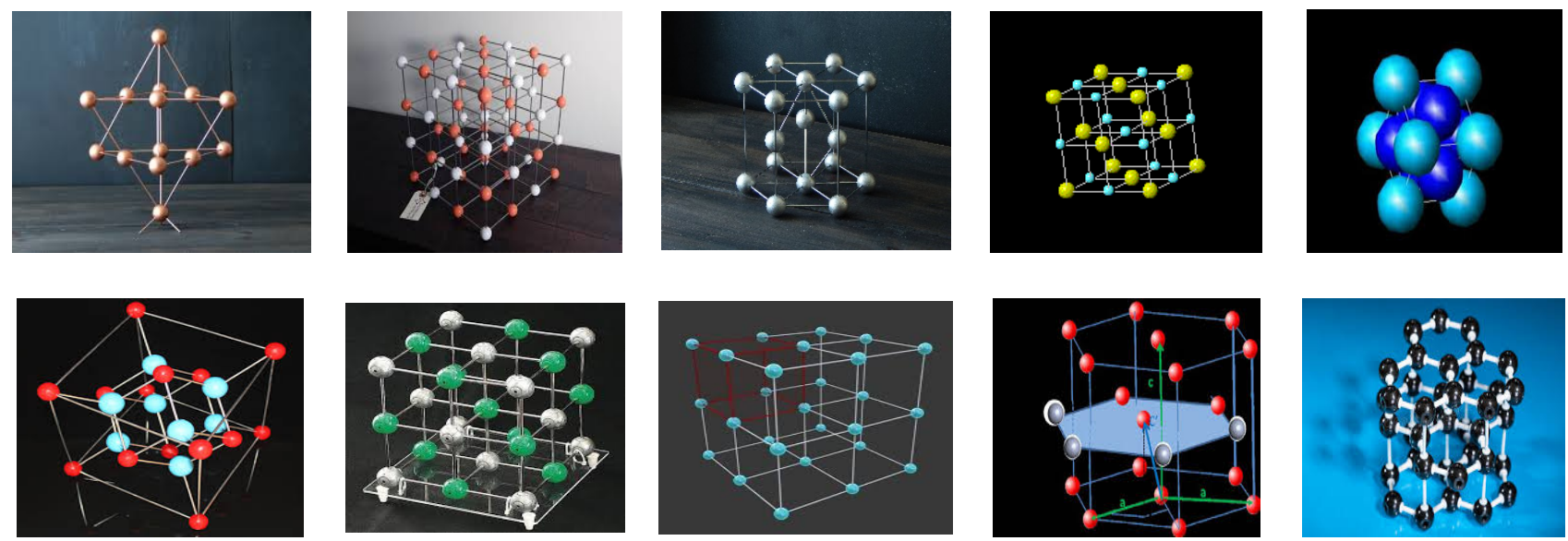

The students create various types of model of unit cell by using waste materials. By joining these handmade unit cells students form crystal lattices. It is an innovative, creative, joyful, interesting, active involvement of learners and an outcome based learning. Learners in the experimental group design and fabricate shapes, pieces and combine, join to form corresponding crystal shape. These students create models which are used for teachinglearning the unit solid state as classroom instruction for Chemistry at Senior Secondary School level. The students of the control group are taught by using traditional stereotype (talk and chalk) method.

\subsection{STATEMENT OF THE PROBLEM}

The present paper is designed to explore the effectiveness of student's handmade model in Chemistry on academic performance of students'. "An Analysis of Impact of Evidence Based Learning on Academic Achievement of Students" is the title of the problem of the present study.

\subsection{OBJECTIVES}

The following objectives are framed to guide the study:

- To investigate the efficiency of the models made by the student on their academic performance in subject Chemistry among the students of Grade 12 .

- To suggest recommendations for the enhancement of the learner's academic performance in subject Chemistry among the students of Grade 12.

\subsection{HYPOTHESIS}

The following null hypothesis are designed for the achieving the above mentioned objectives

$\mathrm{H}_{0} 1$ : There is no noteworthy change on the achievement of the learners of both study group (experimental and control) on pre-test.

$\mathrm{H}_{0} 2$ : There is no noteworthy change on the achievement of the learners of both study group (experimental and control) on post-test.

$\mathrm{H}_{0} 3$ : There is no noteworthy change on the achievement of the learners of both study group (experimental and control) on retention test.

\section{METHODS}

\subsection{POPULATION} population.

All Higher Secondary School students studying Chemistry at the Senior Secondary School level constitute the 


\subsection{SAMPLE AND TECHNIQUES}

Forty students of Grade 12 of Higher Secondary School in rural area are selected. Purposive sampling technique is used to draw the sample. Students are divided into two groups (experimental and control). Each group consists of 20 students.

\subsection{DELIMITATIONS OF THE STUDY}

- The present study is delimited only to the students of one private rural school.

- The study further delimits to the students of Grade 12.

- The study is also delimited to only one unit of Chemistry- solid state.

\subsection{RESEARCH DESIGN}

Experimental research design is employed. The pre-test -post-test equivalent group design is applied. Students are randomly adjusted to both groups and the following symbolic representations of study devices are used:

$$
\begin{array}{lll}
R E=01 & T & 02 \\
R C=03 & T & 04
\end{array}
$$

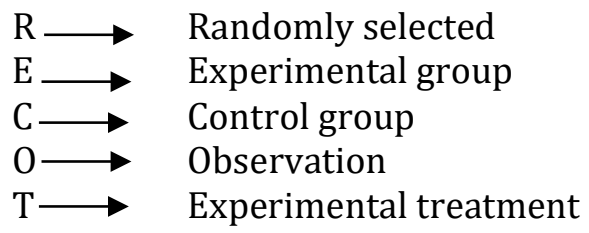

\subsection{TOOL}

Experimental research design is employed. Test-pre and test -post method is used to collect the data. Question paper is made on the unit "solid state" in Chemistry based on the source of revised Bloom's Taxonomy and distributed to both the groups before treatment.

Another question paper is made and distributed to the learners of both groups after the treatment. The two question papers which are applied to the present research are the tools for collecting data.

\section{Revised Blooms Taxonomy}
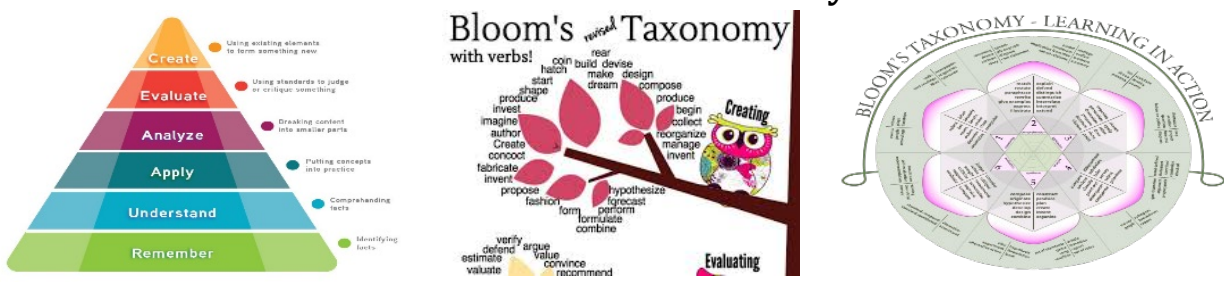

Table 1: Blue print of the Question Paper

\begin{tabular}{|c|c|c|c|}
\hline Sl. No & Domains & Level & \% of the question \\
\hline 1 & Remember & Low cognitive & 7.5 \\
\hline 2 & Understand & Low cognitive & 17.5 \\
\hline 3 & Apply & Middle cognitive & 25 \\
\hline 4 & Analyze & Middle cognitive & 25 \\
\hline 5 & Evaluate & High cognitive & 17.5 \\
\hline
\end{tabular}


An Analysis of Impact of Evidence Based Learning on Academic Achievement of Students

\begin{tabular}{|c|c|c|c|}
\hline 6 & Create` & High cognitive & 7.5 \\
\hline & & Total & 100 \\
\hline
\end{tabular}

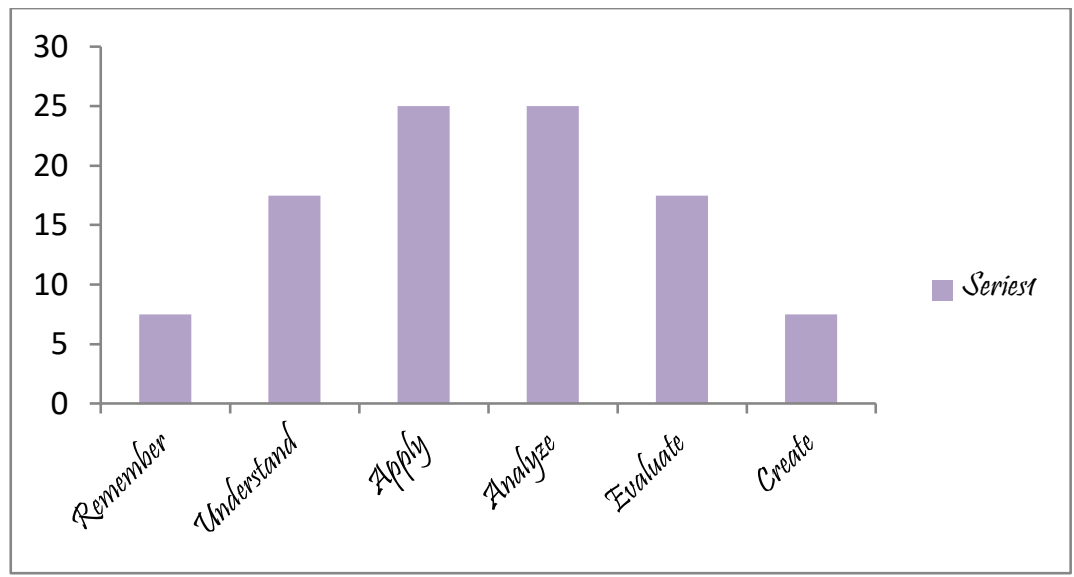

Figure 3: Blue print of the question paper

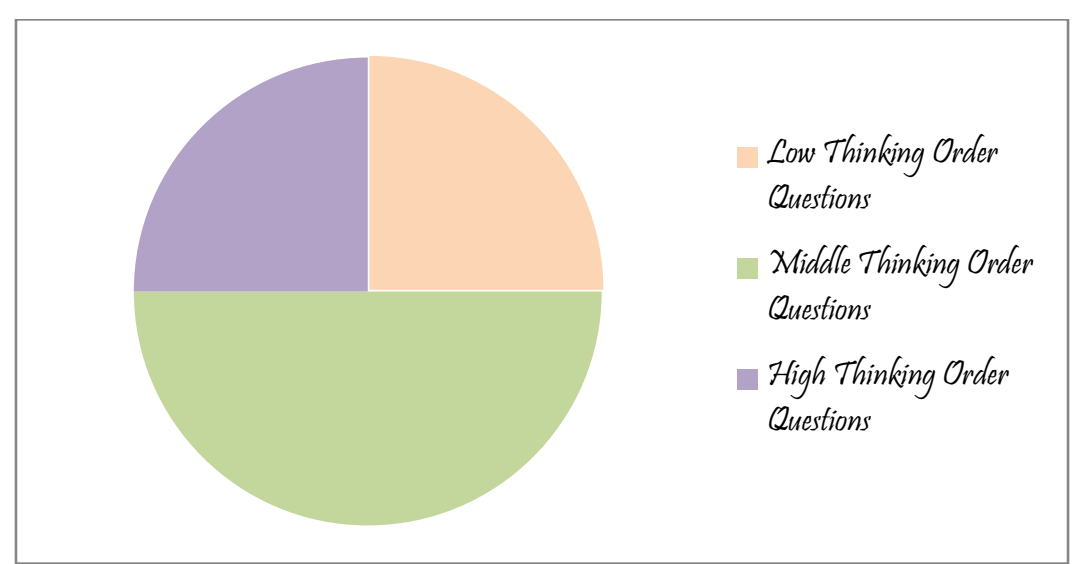

Figure 4: Distribution of Questions based on thinking order (low, middle and high)

\subsection{DATA COLLECTION}

To collect the data pre-test -post-test and retention test was applied to both study groups (Experimental and Control). Question paper were developed coved unit of solid state of chemistry of Grade 12. Raw data collected by conducting the unit -test (pre-test -post-test and retention test).

\subsection{ANALYSIS OF DATA}

The test is conducted before the treatment and after the treatment and is presented in the tabular form. Mean, standard deviation, mean difference is calculated as statistical tool. Significance difference between the groups of mean score for both groups (experimental and control) on variables of pre-test-post-test and retention test is checked at 0.05 level by applying three-unit tests.

\section{RESULT AND DISCUSSIONS}

Table 2: pre-test score

\begin{tabular}{|c|c|c|c|c|c|c|}
\hline Groups & $\mathrm{N}$ & Mean & SD & SE & t-value & p-value \\
\hline Experimental & 20 & 46.29 & 2.38 & 0.74 & 0.049 & 9.57 \\
\hline Control & 20 & 43.25 & 2.48 & & & \\
\hline
\end{tabular}

Non-significant $(\mathrm{p}>0.05) \mathrm{df}=38$

$\mathrm{t}$ (table value) at $0.05=2.02$ 
Prashant Thote, and Gowri. S

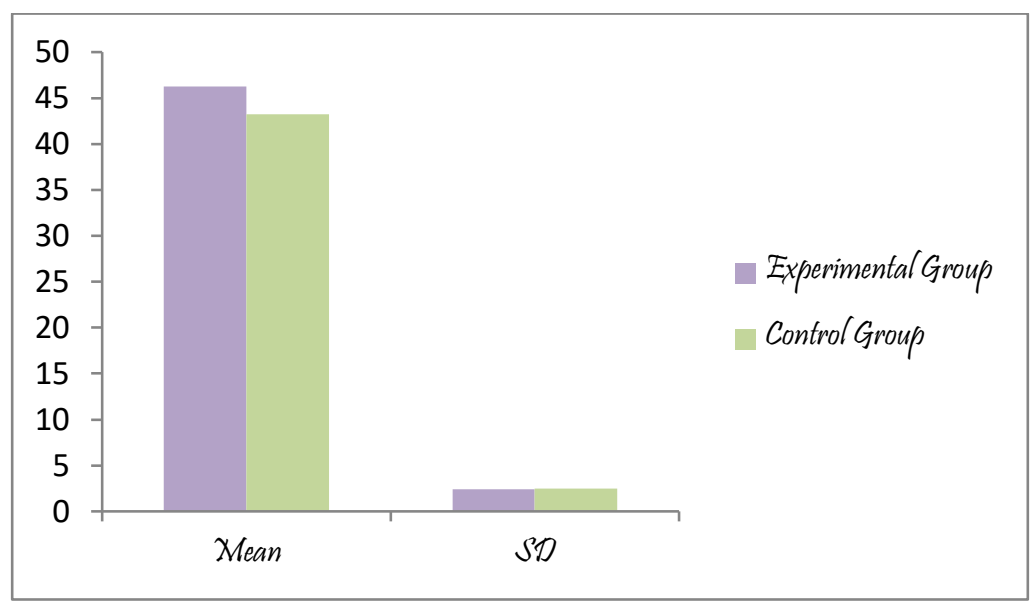

Figure 5: Pre-test score (Mean and SD)

Table 3: Post-test Score

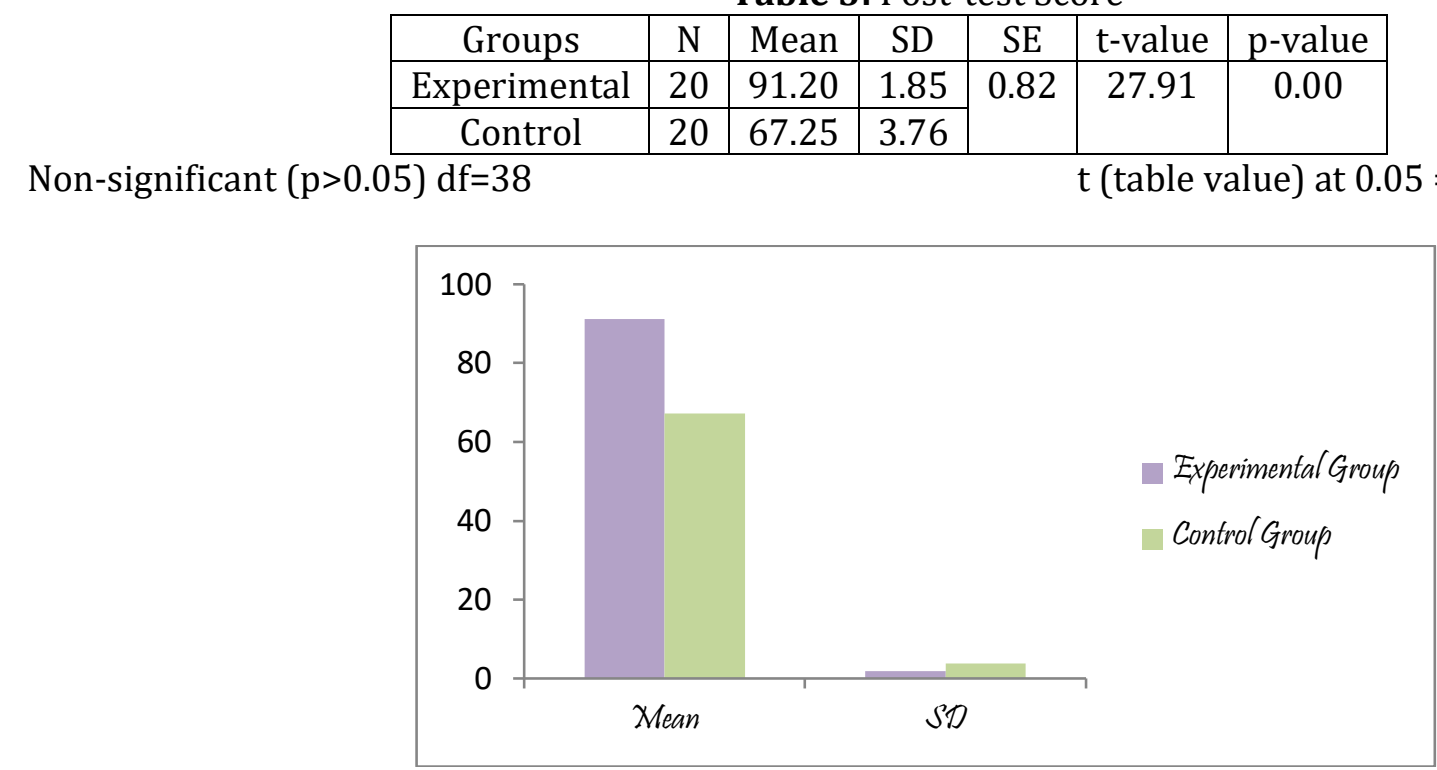

Figure 6: Post-test score (Mean and SD)

Table 4: Retention Score

\begin{tabular}{|c|c|c|c|c|c|c|}
\hline Groups & $\mathrm{N}$ & Mean & SD & SE & t-value & p-value \\
\hline Experimental & 20 & 88.69 & 2.48 & 0.060 & 83.19 & 0.00 \\
\hline Control & 20 & 64.69 & 1.89 & & & \\
\hline
\end{tabular}

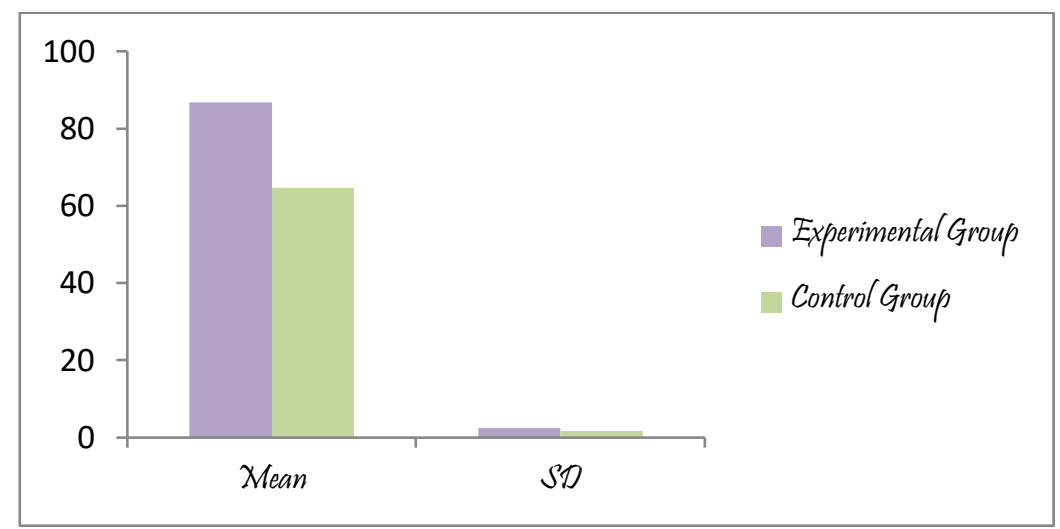

Figure 7: Retention test score (Mean and SD) 
The intention of the study is to probe the effect of hand made models on student's academic performance of Senior Secondary School in Chemistry. The student of the study group (Experimental) is taught the unit solid state by using studnets' hand made model and control group is taught by using traditional chalk and talk method. The conceptual objectives of the units are:

- General characteristics of solid states

- Crystaline and amarphous solids

- Classification of crytaline solids

- Crystallography

- Space lattics/crystal lattics/unit cells

- Types of unit cells

- Calculation of the number of points (particles o atoms) in a unit cell

- Closed paket structures

- Tetrahedral/octahedral voids/interstitial sites

- Formation of compounds and number voids filled

- Stability of ionic crystalline solids in terms of Radii of cations and anions.

- Packing efficiency

- Structures of simple iconic crystals

- Calculations involving unit cell dimensions

- Imperfections or defects in crystalline solids

- Types of point defects

- Nature of bonding in metallic solids

- Properties of solids

- Electrical properties of solids

- Magnetic properties of solids

The solid state unit is covered in 25 periods with 45 minutes duration and treatment lasts for two weeks. After two weeks, Chemistry teacher conducts the post-test with the slight changes in the sequence of the questions and a retention test to the test for both groups (experimental and control group). Data is collected and compared. The complete statistical process is as under.

$\mathbf{H}_{\mathbf{0}} \mathbf{1}$ : There is no significant change on the achievement of the learners of both study group (experimental and control) on pre-test.

Result in Table -3 shows that the calculated t-value is found to be 0.009 which is statistically non-significant, as it is less than critical value $\mathrm{t}=2.02$ at 0.05 level.

Hence the null hypothesis "There is no significant change on the achievement of the learners of both study group (experimental and control) on pre-test" is rejected and accepted. Result unanimously shows that learners of both groups show equal performance on pre-test.

$\mathbf{H}_{\mathbf{0}}$ 2: There is no noteworthy change on the achievement of the learners of both study group (experimental and control) on post-test.

Result in Table- 4 depicts that the computed value of $\mathrm{t}$ is found to be 27.91 and it is statistically significant and is more than the critical table value of $t$ at 0.05 level. Hence null hypothesis "there is no noteworthy change on the achievement of the learners of both study group (experimental and control) on post-test" is rejected and is not accepted. It clearly indicates that the learners of experimental group show significantly excellent performance as compared to the learners of control group on post-test.

$\mathbf{H}_{0} 3$ : There is no noteworthy change on the achievement of the learners of both study group (experimental and control) on retention-test.

Result in Table -5 indicates that the computed t value is found to be 33.19 and statistically significant and is greater than that of the table value of $t$ at 0.05 level. Hence the null hypothesis "There is no noteworthy change on the achievement of the learners of both study group (experimental and control) on retention-test" is not accepted and rejected. It explicitly depicts that the learners of experimental group shows excellent achievement as compared to the learners of the control group in retention test. 


\section{CONCLUSION}

Statistical data analyses of research arrive at the following conclusions:

- There is a significantly positive impact of student's handmade model as outcome-based learning on the academic performance in subject Chemistry at Senior Secondary School level. The outcome-based learning as student's handmade models are effective and efficient in enhancing the achievement level and conceptual understanding in chemistry. It is also useful in identifying the difficult concept in Chemistry for students.

- The students of experimental group show surprisingly better improvement than the learners of control group. The outcome based learning in the form of handmade model of unit cell and crystal lattices in subject Chemistry is highly effective tool by active participation of learners which makes the learners a joyful learning experience and students learns at their own speed and space. Hence it is an individual base learning approach. It acts as a motivational catalyst for the conceptual retention of knowledge, skills and competence.

\subsection{CONCLUDING REMARKS}

In nutshell it is concluded that outcome based learning approach by making handmade model of unit cell and crystal lattice in solid state Chemistry has positive significant impact on academic achievements of learners.

\subsection{RECOMMENDATIONS}

Keeping the view of above conclusion the researcher the following recommendations are made:

- The outcome based learning through making handmade model is very effective and it enhances the performance level of the learners in the subject of Chemistry and hence it may be replicated.

- Chemistry is considered as a difficult subject due to its abstract concept, hence outcome based learning is effective teaching pedagogy.

- Handmade model plays a significant role and it enhances the academic performance in Chemistry as experiential learning activity. Hence it can be used as a teaching aid in classroom instructions.

- Models are powerful teaching tool but must be used with caution in Chemistry. When using the model in classroom instructions keep the following instructions in mind:

- Test your model carefully makes sure that it gives result that you intended in classroom instructions.

- Use model in teaching -learning to enhance the constructs of mental model of concept fully reaches.

\section{SOURCES OF FUNDING}

This research received no specific grant from any funding agency in the public, commercial, or not-for-profit sectors.

\section{CONFLICT OF INTEREST}

The author have declared that no competing interests exist.

\section{ACKNOWLEDGMENT}

None. 


\section{REFERENCES}

[1] Ajunwa, C. (2000), Acquisition of physics process skills by secondary school students, Department of Education, University of Nigeria, Nsukka.

[2] Amanso, E. O.I., \& Bassey, B.A. (2017), Assessment of Selected Science Process Skills Acquisition among Senior Secondary Schools Students in Calabar Education Zone of Cross River State, Nigeria. International Journal of Scientific Research in Education, 10(1), 119-126

[3] Ayas, A., Cepni, S., Akdeniz, A., Ozmen, H., Yigit, N., \& Ayvaci, H.S. (2007), Science and Technology Teaching from Theory to Application (6th Ed.). Ankara; Pegem A Publishing.

[4] Terniz, B.K., Assessing Science Process Skills in Physics Teaching (Ph.D. Thesis). Gazi University, Institute of Education Science, Ankara, Turkey.

[5] Prashant Thote, Experiential Learning: Inclusive Art Education for Joyful Learning, Review of Research, Vol 8, Issue- 09, June 2019.

[6] Prashant Thote, Experiential Learning: Model for Teaching Science at Grade Nine, Research Magma, Vol-3, Issue -06, August - 2019. 